\title{
MODULAR SOLID-STATE UNIT FOR ELECTROCHEMICAL STUDIES
}

GIENN DIRYHURST*, MURRAY ROSEN AND PHIII' J. IELVING

Department of Chemistry. The University of Michigan, Ann Arbor, Mich. 48104 (U.S.A.)

(Received January isth, 1968 )

A number of electrochemical instruments based on operational amplifiers have been recently described (e.g., ref. $\mathbf{r}-3)$. These units are generally of limited versatility, although GoorsBY AND SAWYER have more recently described a versatile solidstate potentiostat-amperostat which could be used for a variety of electrochemical techniques. The latter paper and SArrH's ${ }^{5}$ excellent discussion of the technique of alternating current polarography prompted us to design an even more versatile unit than that of GoOLSBY AND SAWYIR", which could be used as an alternating current polarograph as well as being suitable or adaptable for many other types of electrochemical studies.

The apparatus developed and subsequently described in detail is suitable for conventional constant potential direct current polarography, alternating current polarography, linear scan voltammetry, cyclic triangular scan voltammetry, and coulometry and macroscale electrolysis at controlled potential. The instrument can be adapted to many other uses; particularly useful circuits are described, for example, in references $2-6$. The performance of the unit in conjunction with a three-electrode configuration electrochemical cell allows it to be used for electrochemical studies on solutions of high resistance.

Excluding the $X-Y$ recorder, the total cost of the instrument is less than Srooo.

\section{INSTRUMENTATION}

\section{Instrument arrangement}

Each of ten operational amplifiers is so mounted that their functional terminals are connected to identical sets of banana jacks mounted onto the front panel of a suitable cabinet, e.g., a recessed panel mounting chassis; outlets for the +15 and - I5 V power supply are also provided within each set of jacks, giving a total of nine jacks per set. The panel layout is shown in Fig. I; numbers refer to amplifier terminals, which are the same for all the amplifiers used except the P66A current booster amplifier ( $U$ nit $\mathrm{H}$ ) and $\mathrm{P} 6 \mathrm{r}_{54}$ voltage booster amplifier, where normally keying terminal 4 replaces terminal 3 . A strict color code was employed: red, $+\mathrm{I}_{5} \mathrm{~V}$; yellow, $-x_{5} \mathrm{~V}$; black, ground; green, amplifier inputs; blue, amplifier output; white, all other terminals. Jacks are 0.75 -in. center-to-center relative to one another on a diamond spacing in a given set of nine.

The electrical components necessary to program each amplifier to perform

* Present address: Department of Chemistry, University of Oklahoma, Norman, Okla. 73069. 
the required operation are mounted within a $2 \times 5.25 \times 3$ in. aluminum mini-box, which has a set of external banana plugs arranged to fit into the set of 9 banana jacks mentioned. All controls, i.e., switches, potentiometer knobs, etc,, are mounted on the front of the mini-boxes (Fig. 2).

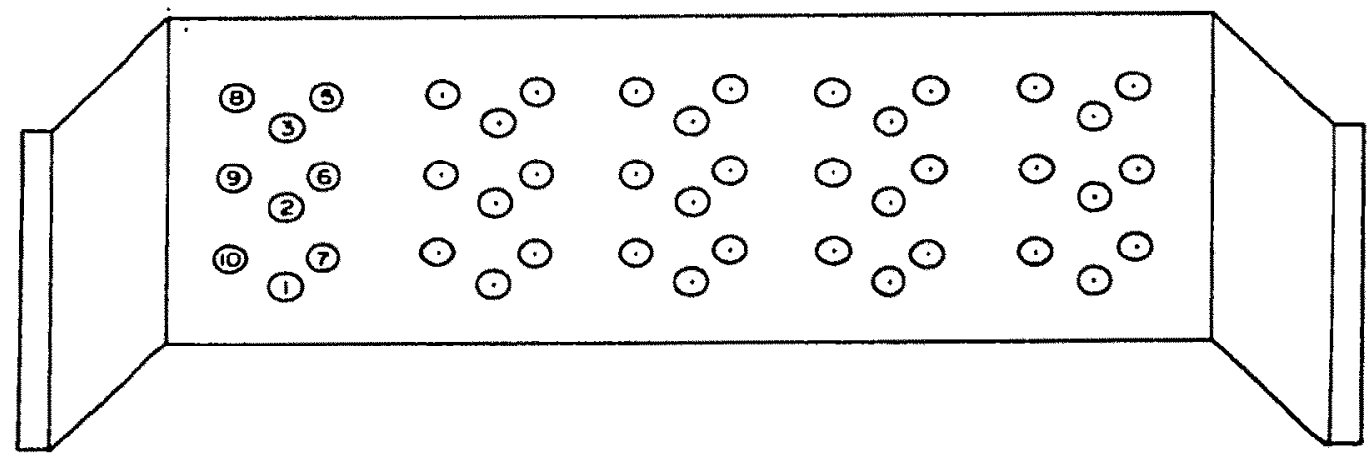

Fig. I. Arrangement of amplifier terminal jacks on a $7 \times 19 \mathrm{in.}$ recessed pancl mounting chassis.

\section{Basic circuit design}

The basic circuit is essentially that of a simple potentiostat (Fig. 3), with provision for boosting the output of the control amplifier with regard to both current and voltage, and with means for converting the signals into forms that can be readily recorded on an $\mathrm{X}-\mathrm{Y}$ recorder.

For convenience, the circuit is divided into a series of individual mechanically discrete units, each enclosed within broken lines on the circuit diagram and designated as Unit A through J. Each unit is mounted in a separate mini-box and will be individually described in respect to construction and function.

\section{Pozer supply}

A Philbrick Model Przoo-R solid-state power supply ( \pm I5 V d.c. ( $\pm 0.01 \%$ ); o to $300 \mathrm{~mA}$ ) was used. When it is necessary to use the P6I54 voltage booster amplifier, two such power supplies are used in order to provide the $\pm 30 \mathrm{~V}$ power requirements for the amplifier?

\section{Sine-wave generator (unit A)}

A very stable sine-wave generator was constructed, which utilizes a Philbrick P65AU amplifier (Fig. 4). REILLEY ${ }^{8}$ has shown that the frequency of the signal from this circuit is given by:

$$
\omega=2 p t /(R C)
$$

where $p$ is the proportion of the output fed back into the input of the amplifier, $R$ is the resistance in ohms of $R_{1}\left(R_{1}=R_{2}\right), C$ is the capacitance in microfarads of $C_{2}$ $\left(C_{2}=C_{3}\right)$, and $\omega$ is the angular frequency $(\omega=2 \pi f$, where $f$ is the frequency in $H z)$. When \pm ro\% capacitors were used, the useful frequency range of the oscillator was between 50 and $250 \mathrm{~Hz}$. The unit is set to oscillate by means of $R_{4}$; the frequency and amplitude are then adjusted by means of $R_{5}$ and $R_{7}$, respectively. 


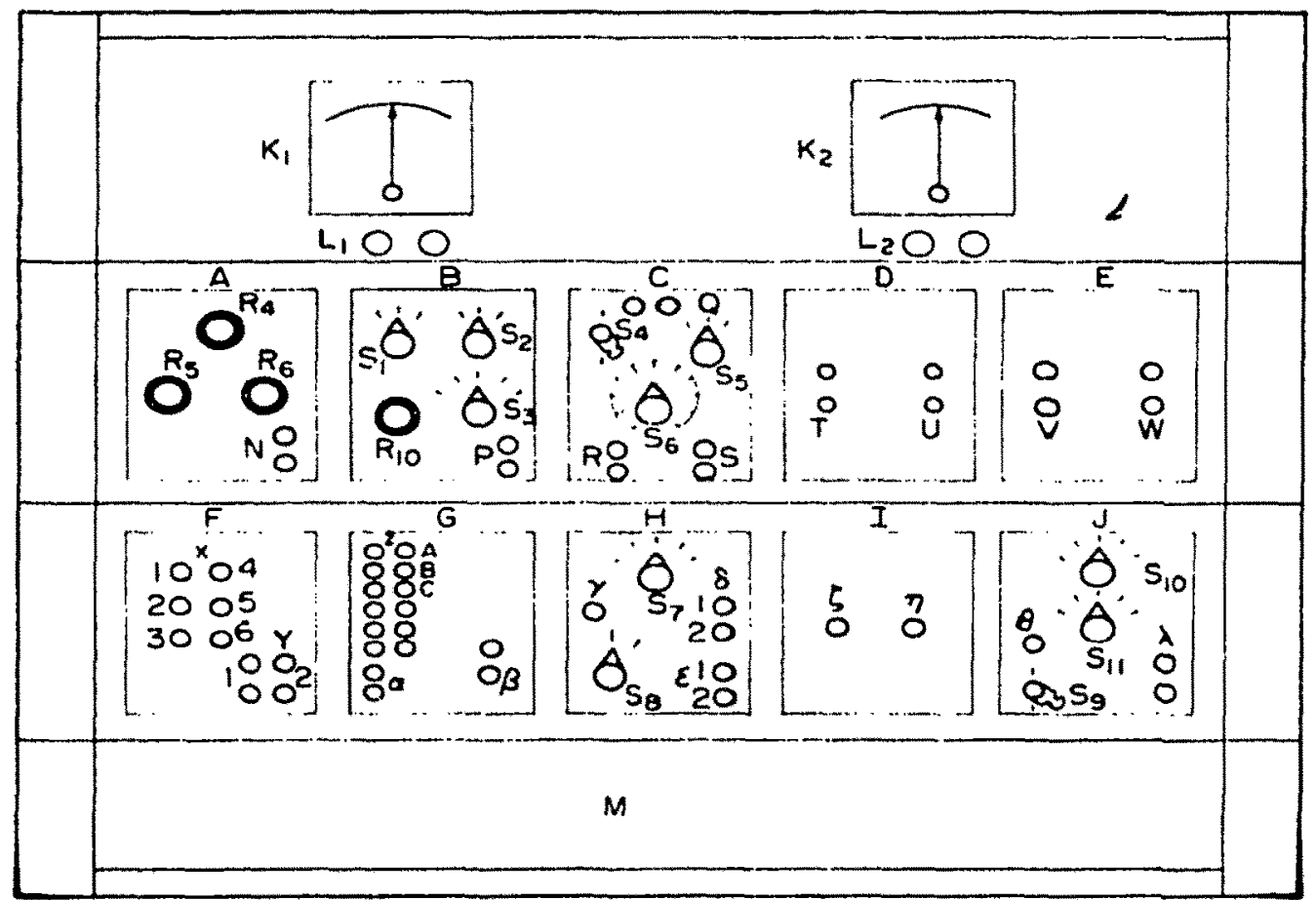

Fig. 2. Arrangement of front of instrument (housed in a 26 -in high conventional 19-in cabinet). The units are mounted on three 7 -in recessed pancl mounting cliassis above the power supply $M$. (A) Sine-wave generator. $R_{4}$, amplifier oscillation adjustment; $R_{s}$, frequency adjust; $R_{6}$, amplitude adjust; $N$, signal output.

(B) D.C. voltage level. $S_{1}$, polarity set (Off-Negative-Positive); $S_{2}$, voltage range set (Off-o to \pm 1.0 volt -0 to \pm 10.0 volt); $S_{3}$, damping acljust; $R_{10}$, voltage adjust; $P$, output voltage.

(C) Ramp generator. Ss, sweep polarity (Positive-Negat ive); $Q$, jacks for $1.0-\mu F$ capacitor; $S_{6}$, integrator function switch (Swecp-Hold-Reset); So, sweep rate set $(2 \mathrm{mV} / \mathrm{sec}$ to $\mathrm{x} . \mathrm{o} \mathrm{V} / \mathrm{sec}$ ); $\mathbf{R}_{20}$. current trim: $\mathrm{IR}$ and $\mathrm{S}$, output jacks.

(D and E) Full-wave rectifier. ' $T$, input from current amplifier; $U$, output to unit $E$; $V$, input fiom unit $D: W$. rectified output signal (to recorder).

(F) Reference electrode follower. $X_{1}$, to reference electrode; $X_{2}$, to counter electrode; $X_{3}$, to working clectrode; $X_{4}$, frcm unit $H_{;} X_{5}$, output from control amplifier (unit $\left.H\right)$; $X_{n}$, input to current amplifier (unit J): $Y_{1}$, output to voltage axis of recorder; $Y_{2}$, output to control anplifier (unit G).

(G) Control amplifier. $Z$, set of 6 identical input jacks; $\alpha$, output jacks to d.c. voltmeter IFi $\beta$, output jacks to current booster amplifier (unit H).

(H) Current booster amplifier. $S_{7}$, booster select (Current Booster-No Booster-Voltage Booster): $S_{8}$, Cell In-Cell Out switch: $\gamma$, output from control amplifier (unit $G$ ); $S_{1}$, outpiut to voltage booster (unit 1 ): $S_{2}$, input from voltage bocster; $\varepsilon_{1}$, output to reference electrode follower ( $X_{4}$ jacle); $\varepsilon_{2}$, to counter clectrode ( $X_{s}$ jack, unit $F$ ).

(1) Voltage booster amplifier. $\zeta$, input from current boostor (jack $S_{1}$ ); $\eta$. output to current booster (jack $S_{2}$ ).

(J) Current amplifier. Sin, damping adjust; $S_{11}$, amplification adjust (I $\mu A=I$ mV-ro m V-100 $\mathrm{mV}-1 \mathrm{~V}$ ): $\theta$, input from working electrode ( $\left.X_{\text {a jack, unit }} \mathbf{F}\right)$; So, cell In-Out switch; $\lambda$, output signal (to recorder or rectifier).

\section{D.C. voltage level (unit $B$ )}

The initial potential of a voltammetric scan or the potential for an exhaustive electrolysis can be set anywhere between + ro and $-\mathrm{ro} V$ by means of a unit based on a Philbrick P65AU amplifier (Fig. 5). The polarity of the voltage is set with $S_{1}$ (note that the output voltage is of opposite sign to the input voltage); the range is 


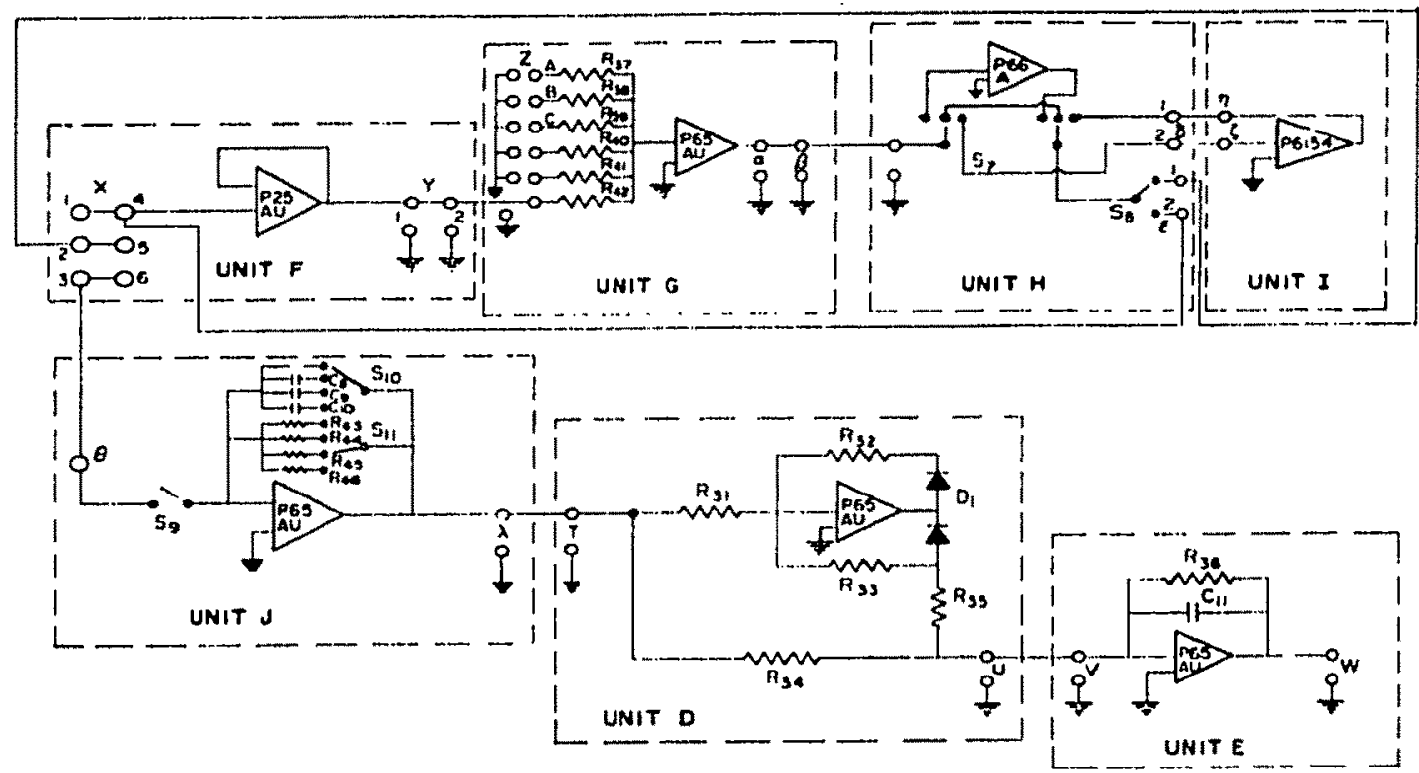

1Fig. 3. T3asic potential control ant meatsuring circuit of instrument. The components are also identified in Fig. 2, where applicalhle, to which reference can be made for items not identified in the present figure caption. Dashed lines indicate circuit within each marked unit. Open circles correspond to banana jacks which appeas on the front pancl of each unit. Solid circles inclicate switching points.

$S_{7,}$ double-pole 3-position shorting: $S_{H_{1}}$ SPDT shorting; $S_{0}, t o g g l e: S_{11}, S_{11}$, single-pole

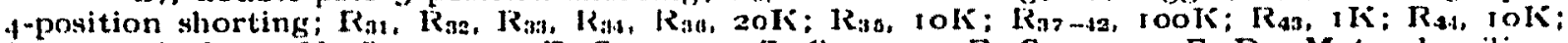

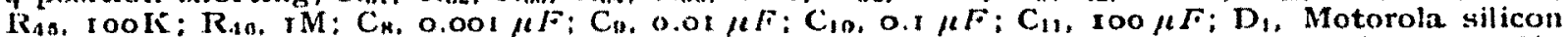
diode, $50 \mathrm{~V} / \mathrm{V}$. Except where otherwise stated, resistors are $\pm 1 \%$ tolerance and capacitors $\pm 10 \%$ : the latter are rated at 6 co $V$ il.c.

$A, 13$ and C: Inputs from units $A$ (Fig. 4), T3 (Fig. 5), and $C$ (Fig. 6), respectively.

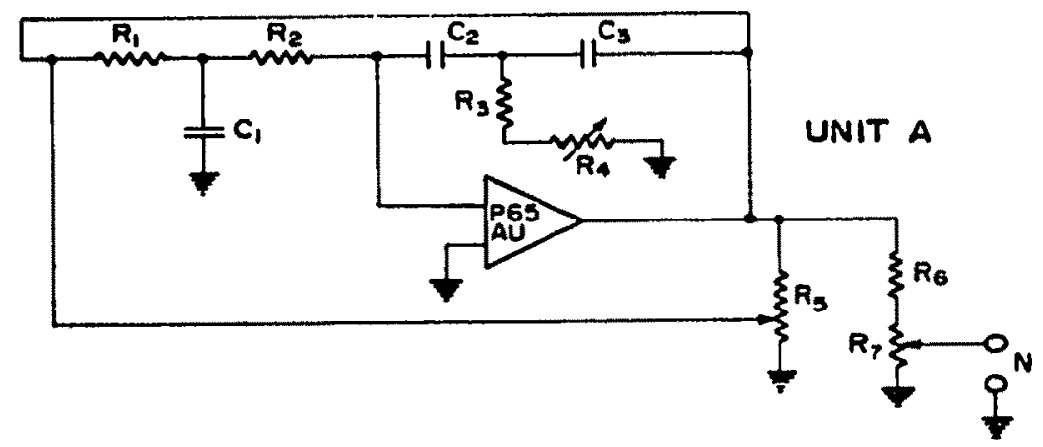

Fig. 4. Sinc-Wave gencrator (unit $\Lambda$ ), $R_{1}, R_{2}, 20 K ; R_{3}, g K ;: R_{4}$, 10-turn, $2 K$ potentiometer: $R_{5}$. ro-turn, 5li potentiometer; $R_{n}, 100 K ; k=$ lo-tum, $1 K$ potentiometer.

changed by altering the magnitude of the input resistors $\boldsymbol{R}_{8}$ and $R_{0}$ to the amplifier by means of switch $S_{2}$. Optional dampening of stray noise is provided for by switch $\mathrm{S}_{3}$ and the associated capacitances.

Ramp generator (unit C)

A suitable ramp generator was built, based on a Philbrick P25AU amplifier

Anal. Chim. Acta, $42(1968) 4_{43-152}$ 


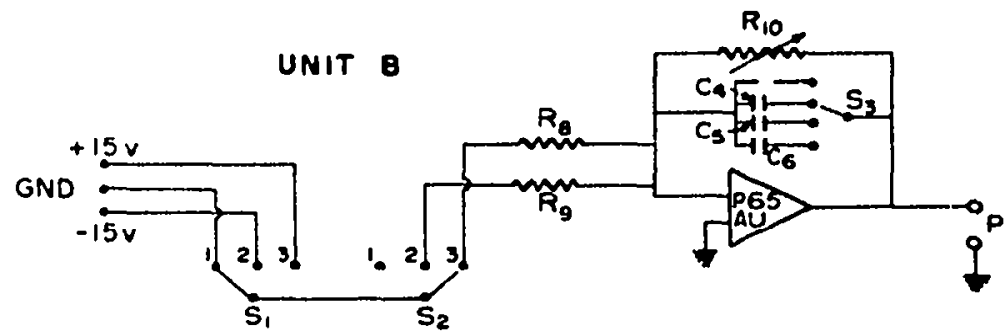

Fig. 5. D.C. voltage level (unit F3). S1. Sa, rotary single-pole 3-position non-shorting: S3, rotary

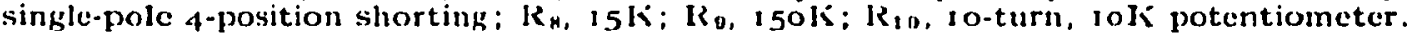

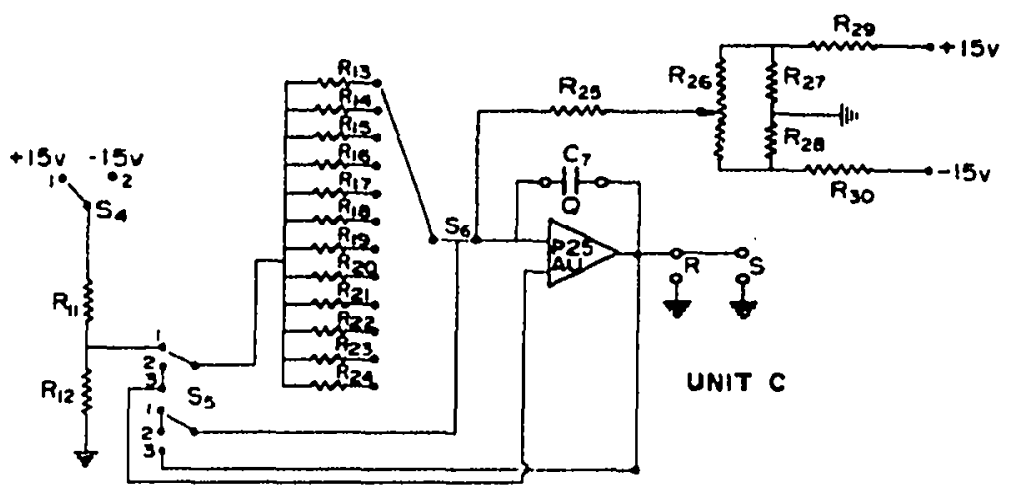

Fig. (). Ramp generator (unit $\mathbf{C}$ ). $\mathbf{S}_{4}$, cloublc-pole 3-position shorting; $S_{b}$, single-pole I I-position shorting: $R_{13,}$ rooK; $R_{14}, 200 \mathrm{~K} ; \mathrm{R}_{15}, 500 \mathrm{~K} ; \mathrm{R}_{16}, \mathrm{IM}: \mathrm{R}_{17}, 2 \mathrm{MI} ; \mathrm{R}_{1 \mathrm{H}}, 5 \mathrm{M} ; \mathrm{R}_{10}, 7.5 \mathrm{M} ; \mathrm{R}_{20}, 10 \mathrm{M}$;

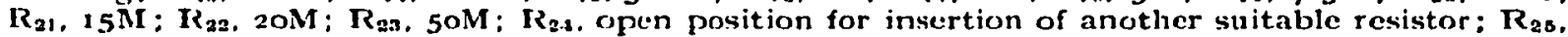

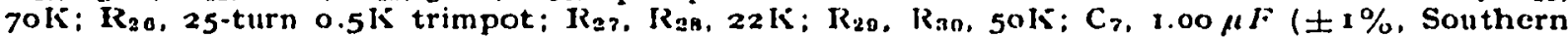
Elcctronics, Burbank, Calif., Moclel PC $105 \mathrm{G} 2 \mathrm{API}, 200 \mathrm{~V}$ d.c.).

(Fig. 6). By variation of the input resistance with switch $S_{6}$, eleven scan rates between 2 and Iooo $\mathrm{mV} / \mathrm{sec}$ can be generated. A I.0-m $F$ polystyrene capacitor is used in feedback. The polarity of the output signal is selected by means of a switch $\mathbf{S}_{4}$. Switch $S_{3}$ selects the mode of the integrator to either sweep, hold or reset. The output of the ramp generator is monitored continuously with a ( + Io)-0-( - Io) V d.c. meter (Eberbach Corp. Model 3or-57).

The performance of the ramp generator was generally very satisfactory, although the minimum drift attainable, $\pm 0.2 \mathrm{mV} / \mathrm{sec}$, became significant for studies requiring very low scan rates, e.g., 2 or $5 \mathrm{mV} / \mathrm{sec}$. However, when an $X-Y$ recorder is used, slight variations of sweep rate are not important. When the performance of the ramp generator becomes critical, a Philbrick $\mathrm{P}_{2}$ amplifier could be used instead of the P25AU.

\section{Full-wave precision rectifier (units $D$ and $E$ )}

A full-wave precision rectifier, based on Howe's design', utilized two Philbrick P65AU amplifiers (Fig. 3). The unit performed well and the output could be fed directly to one axis of an X-Y recorder.

The damping capacitor, $C_{11}$, tended to cause the output on the recorder to be attenuated by a factor of $\mathbf{r . 9 3}$, although this was a linear effect over the normal current ranges expected and could easily be corrected. Without the damping capacitor, 
the current oscillations on the recorder became very large and considerable noise was seen.

Reference electrode follower (unit $F$ )

Because of their high imput impedance and stability, Philbrick PasAU amplifiers were employed in the reference electrode follower, which monitors the potential difference between the reference and working electrodes. The follower was wired in the conventional unity gain, non-inverting mode (Fig. 3 ).

\section{Control amplifier (unit $G$ )}

The control amplifier is based on a Philbrick 1'65AU amplifier. Five identical sets of input jacks are provided so that several signals can be introduced and summed simultaneously (Fig. 3). The state of control of the output of the control amplificr is monitored by means of a $(+\mathrm{ro})-\mathrm{o}-(-\mathrm{ro})-\mathrm{V}$ d.c. meter (Eberbach Corp. Model $30 \mathrm{r}-57)$.

\section{Current booster (unit $H$ )}

The current booster amplifier is a Philbrick 1'66A amplifier, which has a maximum output of $\pm 20 \mathrm{~mA}$ at \pm to $\mathrm{V}$ without external resistors and $\pm 100 \mathrm{~mA}$ at \pm to $V$ with appropriate externally connected resistors ${ }^{10}$.

\section{Voltage booster (unit I)}

In order to achieve high voltage outputs in the control amplifier loop, provision is made for the use of a Philbrick P6I54 voltage booster amplifier capable of $\pm 1.0 \mathrm{~mA}$ at \pm roo $V$. By means of switch $S_{7}$, the current booster or voltage booster can be switched into the circuit or, as is usual, the unit can be used without any booster amplifiers.

In order to prevent the control amplifier from reaching its output limits when the counter and reference electrode leads are disconnected, provision is made by ineans of switch $\mathrm{S}_{8}$, for shorting the two electrodes together internally.

\section{Current amplifier (unit $J$ )}

A Philbrick P65AU amplificr is used in the inverting mode to convert the current flowing at the working electrode into a proportionate voltage which can be fed to a recorder. By means of the feedback resistor (switch $S_{11}$ ), the amplification of the current could be altered to the extent that $I \mu \mathrm{A}$ flowing at the working electrode could be converted to $I$, xo, Ioo or rooo $\mathrm{mV}$.

In order to eliminate high-frequency noise when the unit is used as an alternating current polarograph, it is necessary to have a small damping capacitance across the amplifier. Generally, a $0.001-\mathrm{m} F$ capacitor was preferred since this did not attenuate the a.c. signals to any appreciable extent.

\section{Operating procedure}

Depending upon the operation rcquired, various units are connected together by means of coaxial cable. Thus, for d.c. polarography and voltammetry and for cyclic voltammetry, units $B, C$, and $F$ to $J$ are used, although booster units $H$ and $I$ are not needed for most purposes. 
For controlled potential electrolysis, units B, F, G, and H or I would normally be required.

For alternating current polarography, units $A$ to $G$ are required.

Clearly, by suitable patchcording or, preferably, construction of alternative mini-boxes, many other operations can be performed, e.g., $c f$. references $\mathbf{I}-6$ and $\mathbf{I} \mathbf{r}$.

All voltammograms and polarograms during the testing and subsequent use of the instrument were recorded satisfactorily on cither a Moseley Model r35 or Model 7oorA X-Y recorder.

\section{INSTRUMENT PERFORMANCE}

\section{Inorganic system}

The iron(III)/iron(II) system in $0.25 M$ oxalic acid-0.25 $M$ potassium oxalate solution ( $\mathrm{pH}$ 2.65), which is generally considered to be reversible at the dropping mercury electrode, was examined to evaluate the performance of the instrument. Polarography (d.c.) at the dropping mercury electrode (DME) gave the same results as a Sargent Model XXI polarograph. Linear sweep and cyclic voltammetry at the

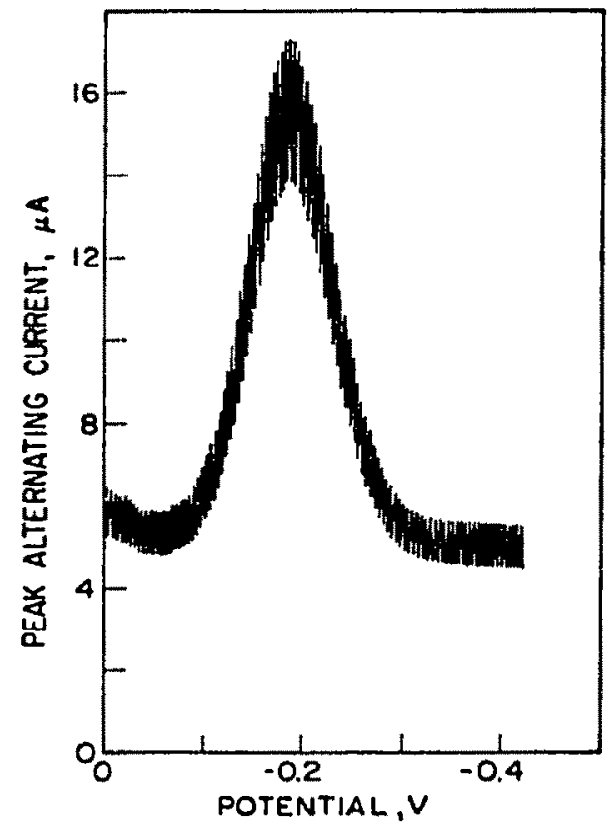

Fig. 7. Alternating current polarogram of $1 \mathrm{~m} M$ iron(III) in oxalate background (pH 2.65 ). Frequency: $50 \mathrm{~Hz}$; amplitude: $30 \mathrm{mV}$ peak-to-peak; scan rate: $2 \mathrm{mV} / \mathrm{sec}$. Potential is $v s$. SCE.

pyrolytic graphite electrode (PGE) and the hanging mercury drop electrode (HMDE) gave results identical to those obtained with a cyclic voltammetry unit based on the original DeFord designs ${ }^{11}$, which utilized vacuum-tube operational amplifiers.

Alternating current polarography at the DME was as expected for a reversible system as evidenced by $(I)$ the linear relationship between the peak current and the amplitude of the alternating signal over the range of $4-40 \mathrm{mV}$ peak-to-peak voltage at $50 \mathrm{~Hz},(2)$ the invariance of the peak current with the height of the mercury 
column, (3) the linear relationship between the peak current and the square root of the applied frecluency between 15 and $64 \mathrm{~Hz}$, followed by a region at higher frequencies where the current rapidly decreased with increasing frequency, and (4) the linear peak current-concentration curve at $50 \mathrm{H} / \mathrm{and}$ the $10-\mathrm{mV}$ peak-to-peak amplitude over the concentration range o.I-I $\mathrm{m} M$. A typical a.c. polarogram is shown in lig. 7 .

The observed alternating current was lower than that predicted theoretically'2, primarily because of the uncompensated capillary resistance of the clropping mercury electrode. By means of recently published circuits ${ }^{13}$, it should be possible to reduce substantially the effects of the scries resistance.

The un it is capable of performing only fundamental harmonica.c. polarography, although it would be possible-by increasing the number of operational amplificrsto extend the unit to perform sccond and third harmonic a.c. polarographys.

Organic system

Purine, which gives two 2-electron waves at the dropping mercury electrode

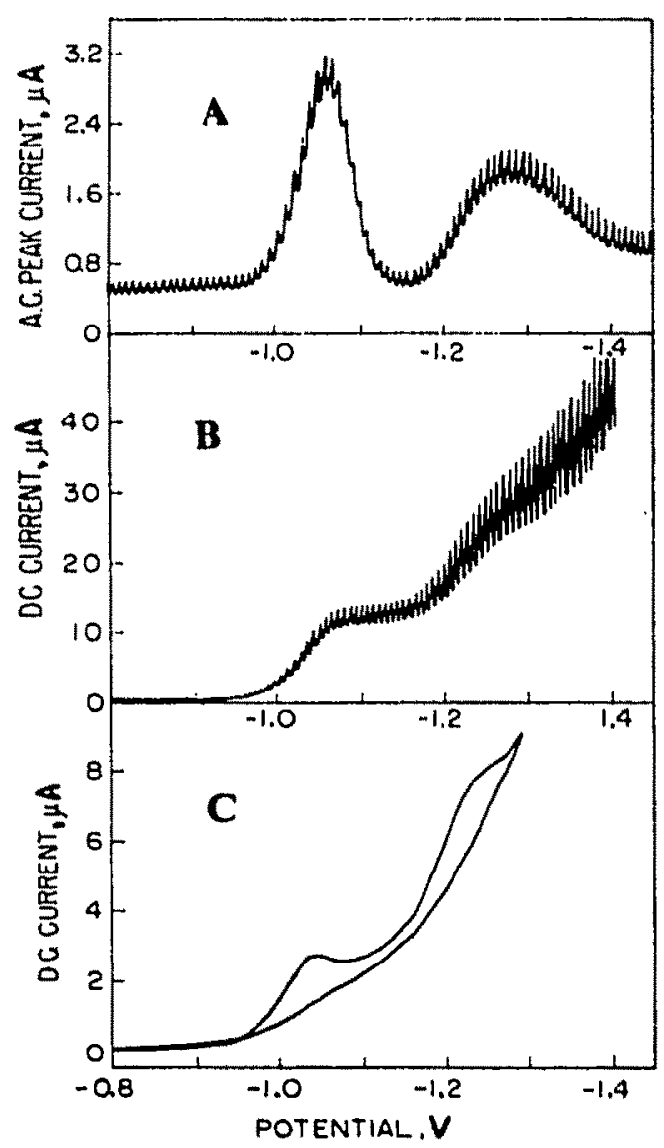

Fig. 8. Response of purine in prr $4 . x$ aqueous acctate buffer solution (ionic strength: $0.5 M$ ). (A) Alternating current polarography at DME; d.c. $\operatorname{scan}$ rate, $2 \mathrm{mV} / \mathrm{sec}$; a.c. amplitude, ro $\mathrm{mV}$ peak-to-peak; frequency, $50 \mathrm{~Hz} ; 2 \mathrm{mM}$ purine. (B) D.C. polarography at DME; scan or polarization rate, $2 \mathrm{mV} / \mathrm{sec} ; 2 \mathrm{mM}$ purine, (C) Cyclic voltammetry at hanging mercury drop electrode; scan rate, $20 \mathrm{mV} / \mathrm{sec} ; 0.5 \mathrm{~m} M$ purine. Potential is vs. SCE. 
in acidic solution with some catalytic hydrogen evolution accompanying the second wave ${ }^{14}$, was examined in $0.5 M$ acetate buffer solution of $\mathrm{pH}$ 4.I. Curves obtained on polarography at the DME, cyclic voltammetry at the hanging mercury drop electrode, and alternating current polarography at the DME are shown in Fig. 8.

The polarographic data agree with those previously reported for a Leeds \& Northrup Type E Electro-Chemograph ${ }^{14}$; the cyclic voltammetric and a.c. polarographic data agree with those obtained with separate units based on vacuum-tube operational amplifiers ${ }^{15}$.

Of special significance from the analytical viewpoint is the definition of the second purine wave on a.c. polarography as compared to that on d.c. polarography.

The authors thank the National Science Foundation, which helped support the work described, Mr. Victor Popolak, who constructed the instrument, and Mr. Conrad O. Schmakel, who helped with the testing.

SUMMARY

A relatively inexpensive unit based upon solid-state operational amplifiers is described; its modular design makes it an extremely versatile instrument for many electrochemical techniques, e.g., normal direct current polarography and linear sweep voltammetry, cyclic voltammetry, alternating current polarography, and coulometry and electrolysis at controlled electrode potential. It can be readily adapted to many other functions.

RRŚSUM

Une unité modulaire solide relativement peu coûteuse est décrite constituant un instrument extrêmement versatile pour de nombreuses techniques électrochimiques: polarographie à courant direct normal et voltammétrie à balayage linéaire, voltammétrie cyclique, polarographie à courant alternatif, coulométrie et électrolyse à potentiel contrólé. Cet appareil peut être facilement adapté à plusieurs autres usages.

\section{ZUSAMMENTASSUNG}

Es wird eine relativ kleine Verstärkereinheit, welche sich für zahlreiche elektrochemische Techniken wie z.B. die Polarographie, Voltametrie, Coulometrie und für die Elektrolyse eignet, beschrieben. Sie kann ebenso schnell zahlreichen anderen Funktionen angepasst werden.

\section{REFERENCES}

I G. L. Boomax aNd W. B. Holbrook, Anal. Chem., 37 (1965) 795.

2 OPERATIONAI AMPLIFIER SYMPOSIUM, Anal. Chem.. 35 (1963) 1770.

3 SYM POSIUM ON ELECTROANALYTICAL INSTRUMRNTATION, Anal.Chem.. 38 (1966) 1 106.

4 A. D. Goolsby and D. T. Sawyer, Anal. Chem. 39 (1967) 4 T1.

5 D. E. Smith, in A. J. BARd, Electroanalytical Chemistry, Vol. 1, Marcel Dekker, New York, 1966, Chapter 1. 
6 H. V. Malnstadt, C. G. ENke and E. C. Toren, Electronics for Scientists, Benjamin, New York, 1963 .

7 Philerick resen rehes inc, Philbrich Model 6154-25 Voliage Booster Amplifier. Preliminary Technical Information.

8 C. N. IRILLeY, J. Chem. Fdiec., 39 (1902) ^853, A933.

9 12. Hown, Instr. Conlrol Syslems, $34\left(\mathrm{r}_{961)} \mathrm{I}_{4} 82\right.$.

ro PHillerick REszarcines inC., data shcet on Model P66A-High Performance Booster Follower.

It D. D. DeFond, 133ral Meeting American Chemical Sociely, San Francisco, Calif., 1958.

12 B. BRTYUR AND H. H. BAUER, Alternating Current Polarography and Tensammetry, Interscience Publishers, New York, 1963, p. 47

13 E. R. Brown, T. G. McCord, D. E. Smitrh AND D. D. DeFond, Anal. Chem., 38 (1966) atig.

14 D. L. Smitu and P. J. Elving, J. Am. Chem. Sog., 84 (19Gz) iqtz.

15 G. DRYiturst AND $\mathrm{P}^{3}$. J. ELVING, work in progress.

Anal. Chim. Acla, 42 (1968) $143^{-152}$ 